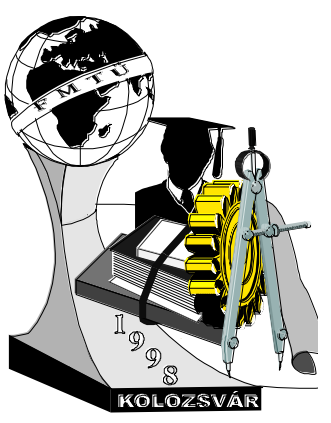

\title{
Az anyagjellemzők hatása a redukált cső alakjára
}

\author{
Klementis Ottó, Gál Gaszton
}

\begin{abstract}
In this paper the numerical and experimental method for determination of final form of extruded tube will be described. The effect of variation of material parameters will be studied using the Pam-Stamp simulation package. The results make possible the tool optimisation for given tube shapes.
\end{abstract}

\section{Bevezetés}

Az alakítási gyakorlatban igény van arra, hogy egy csőszerű előgyártmány egyik, vagy mindkét végét adott szakaszon meghatározott méretüre kell csökkenteni. Ezt az alakítási feladatot csőredukálási müvelettel lehet elvégezni, amelynek az a lényege, hogy a csövet nyomóerővel kúpos bemenetü alakítószerszámba sajtolják a kívánt hosszon, majd kitolják az alakítószerszámból. Számos tudományos munka foglalkozik a csőredukáláshoz szükséges erő és teljesítmény meghatározásával. Ezen munkák az alakított cső képlékeny tartományához tartozó anyagrészre felírt differenciál-egyenletrendszer alkalmas egyszerüsítések figyelembe vételével való megoldására épülnek. Általában zártalakú közelítő összefüggéseket vezetnek le eredményül, amelyek segítségével meghatározható az alakítás erő- és munkaszükséglete, ellenőrizhető a redukálás elvégezhetősége, meghatározható az a határ-méretviszony, amelynél éppen nem zömül meg a cső az alakító kúp elött. Az egyenletrendszer megoldhatósága érdekében gyakran durva közelítéseket használnak. Figyelmen kívül hagyják azt a tényt, hogy az alakításkor a cső falvastagsága változik, vagy figyelembe veszik ugyan a csőfal vastagodását, viszont a

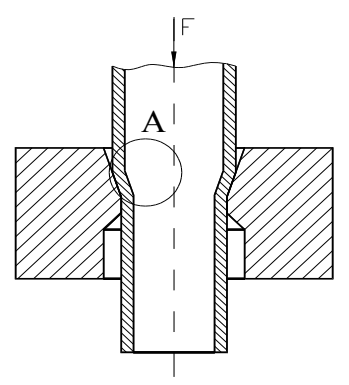

Elméleti

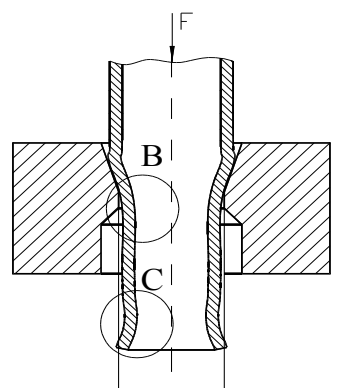

Gyakorlati
1. ábra. A redukált cső elméleti és gyakorlati alakja cső falvastagság változását lineárisnak tekintik. Általában eltekintenek attól, hogy a cső az alakítókúp előtt is és utána is alakváltozik. Az eddigi munkák nem foglalkoznak a cső alakítás utáni méret-pontosságával, az alakítószerszám és a redukált csőrész méreteinek kapcsolatával. Jelen munka az anyag keményedési jellemzői és a csőredukálás során alakított csőrész méretei közötti összefüggés meghatározását tü zte ki célul. 


\section{A probléma megfogalmazása}

A csőredukálásra vonatkozó szakirodalomban található összefüggéseket elemezve megállapítható, hogy ezek a képletek azért sem adhatnak lehetőséget a redukálás utáni csőméretek kellő pontosságú meghatározására, mert a redukáláskkor az alakított csőrész tényleges alakja és mérete a 1 . ábra szerint jelentősen eltér az elméletileg várható alaktól. A cső kis mértékben megzömül az alakítómatrica előtt, a redukált rész külső átméröje kisebb, a vége pedig nagyobb lesz az alakítómatrica üregének méretétől, a falvastagsága nagyobb a kiinduló falvastagságnál. Ezekből következik egyrészt, hogy a matricát nagyobb méretüre kell készíteni az előírt névleges átmérőnél, másrészt hogy a redukált cső kitolásakor is alakítást kell végezni, ezért jelentős nagyságú erőt igényel a darab kidobása.

Alakításkor a redukált csőrész tényleges méretei számos tényező együttes hatásának eredményeként alakulnak ki. Ezek közül a legfontosabbak a következők: a cső alakítás elötti és utáni külső átmérőinek viszonya, az alakítandó cső átmérőjének és falvastagságának viszonya, a cső anyagának jellemzői, az alakítómatrica átmérője és kialakítása, és a matricában a redukáláskor kialakuló tényleges súrlódási viszonyok. A csőredukálási technológia megtervezéséhez mindenképpen szükség van ezen tényezők szerepének ismeretére. A technológiai adatokat alakítási kísérletekből is meg lehet határozni, azonban ez nagyon költséges. Ezért a csőredukálási paraméterek hatásának vizsgálatát végeselemes analízisre épülő számítógépes szimulációval végeztük.

A redukálás szimulációs vizsgálatához $14^{\circ}$-os félkúpszögü kúpos szerszámot használtunk. A csőelőgyártmány külső átmérőjét $\$ 33.7 \mathrm{~mm}$-re, a falvastagságot $6 \mathrm{~mm}$-re vettük fel. A csőredukálási folyamat PAM-STAMP végeselemes programrendszerrel való szimulációjához a kezdeti hálózást olyan módon kell megválasztani, hogy az lehetővé tegye a végeselemháló későbbi adaptív finomítását. Az automatikus áthálózás akkor következik be, ha a számított alakváltozási intenzitás valamelyik elemben meghalad egy adott értéket, vagy a szomszédos felületelemek normálisai által bezárt szög nagyobb 70_ nál. Az alakítandó anyag alakítási szilárdságnak leírására a Nádai-féle összefüggést alkalmaztuk, amelynek általános alakja $\boldsymbol{k}_{f}=\boldsymbol{C}_{0}\left(\varphi+\varphi_{0}\right)^{n}$, ahol $k_{f}$ az alakítási szilárdság, $C_{0}$ és $n$ anyagállandók, $\varphi_{0}$ az előgyártmány előzetes alakításának mértéke, $\varphi$ a csőredukálásakor bevitt alakítási intenzitás. A redukálás szimulációjakor az alakítómatrica és a cső között Coulomb-féle súrlódás tételeztünk fel, a súrlódási tényezőt 0,12-re választottuk. Az szimulációkat az 1. táblázatban feltüntetett anyagjellemzőkkel végeztük el.

1. táblázat. A különböző anyagokkal számolt geometriai jellemzők

\begin{tabular}{|c|c|c|c|c|c|c|}
\hline \multicolumn{3}{|c|}{ Anyagjellemzők } & \multicolumn{4}{c|}{ A számolt jellemzö adatok } \\
\hline$C_{O}$ & $\varphi_{\mathrm{O}}$ & $n$ & abs min & up points & abs max & türésmező \\
\hline 125 & 0.0084 & 0.24 & 0.477 & 1 & 0.043 & 0.418 \\
\hline 625 & 0.0084 & 0.24 & 0.427 & 2 & 0.252 & 0.255 \\
\hline 975 & 0.0084 & 0.24 & 0.411 & 2 & 0.346 & 0.207 \\
\hline 625 & 0.1 & 0.24 & 0.389 & 2 & 0.315 & 0.232 \\
\hline 625 & 0.06 & 0.24 & 0.404 & 2 & 0.296 & 0.240 \\
\hline 625 & 0.0084 & 0.14 & 0.530 & 2 & 0.230 & 0.371 \\
\hline 625 & 0.0084 & 0.44 & 0.648 & 1 & 0.073 & 0.423 \\
\hline
\end{tabular}


A számítási eredmények ellenőrzésére az előzők szerinti szerszám- és cső méretek felhasználásával alakítási kísérleteket végeztünk XC32 anyagminőségü $(C=0.32 \%)$ acélcsővel, amelynek folyási görbéjét Watts-Ford módszerrel határoztuk meg. A szimulációs számítási és a kisérleti eredmények eltérése nem haladta meg a 15\%-ot. Ez a hiba azzal magyarázható, hogy a súrlódási viszonyok számításokban figyelembe vethető módja eltért a gyakorlati alakításnál fellépő súrlódástól, valamint az, hogy a PAMSTAMP programrendszert lemezalakítási feladatok megoldására fejlesztették ki, ezért a viszonylag

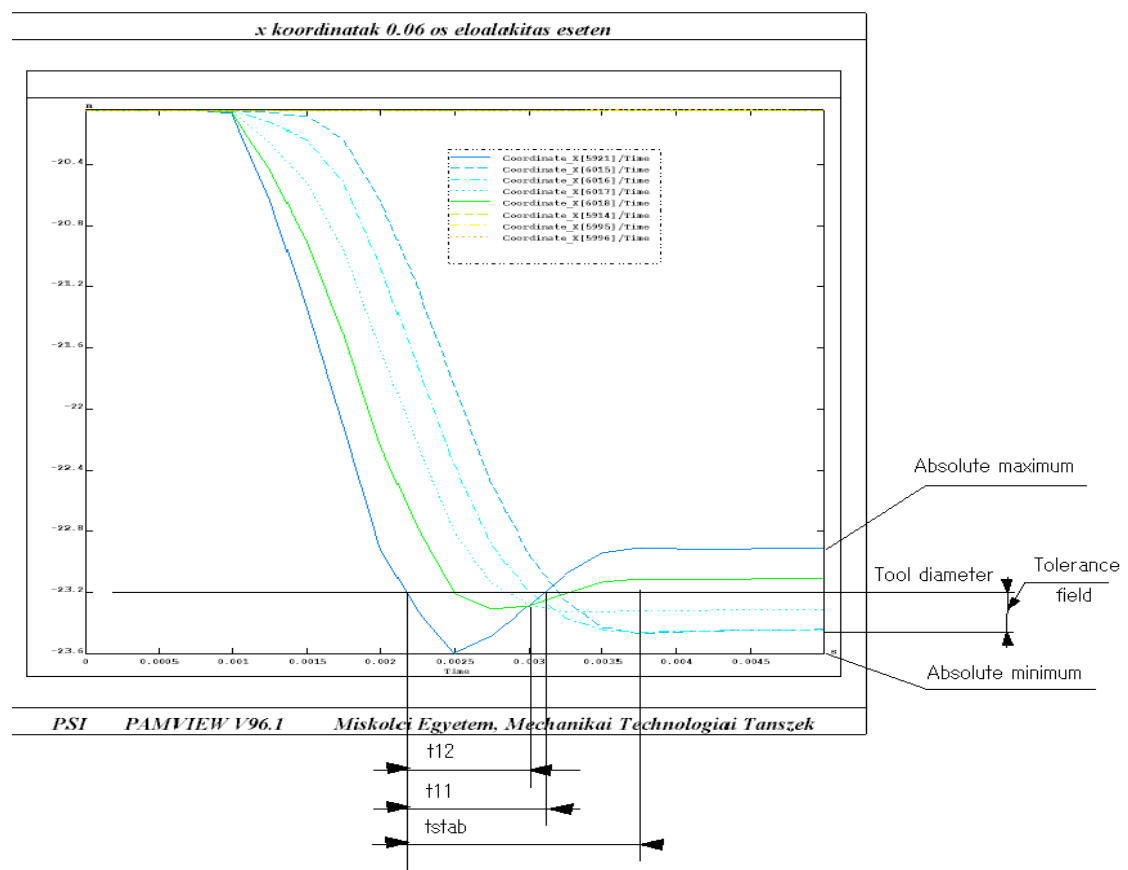

2. ábra. Radiális helykoordináta-idő diagramok vastag falú cső redukálásának analizálásakor hibák adódhatnak.

A szimulációknál figyelemmel kísértük a külső felület egy meridián metszetét, ezen vizsgáltuk a jellemzö pontok koordinátáinak változását $\mathrm{az}$ alakítás folyamán. Tekintettel arra, hogy az alakítószerszám sebessége a folyamat során állandó, diagramból meghatározható a cső külső alakja minden alakítási fázisban. A diagramok alakja egy konkrét esetben a 2. ábrán látható. A végeselemes programrendszerrel előállított nagy mennyiségű adathalmazt egy erre a célra készített grafikus programmal dolgoztuk fel. A vizsgálat a következők jellemző adatokra terjedt ki: a matrica átmérőjétől való legkisebb (abs min), illetve a legnagyobb (abs max) eltérés, a kidobás utáni türésmező, valamint azon pontok száma (up points), amelyek a redukáló matrica kalibráló részénél nagyobb átmérőjüek. A különböző anyagok esetén számolt jellemző adatokat az 1. táblázat tartalmazza.

A 3.-5. ábrákon grafikusan ábrázoltuk a redukált csőrész méreteinek elérését a szerszám méretétől a

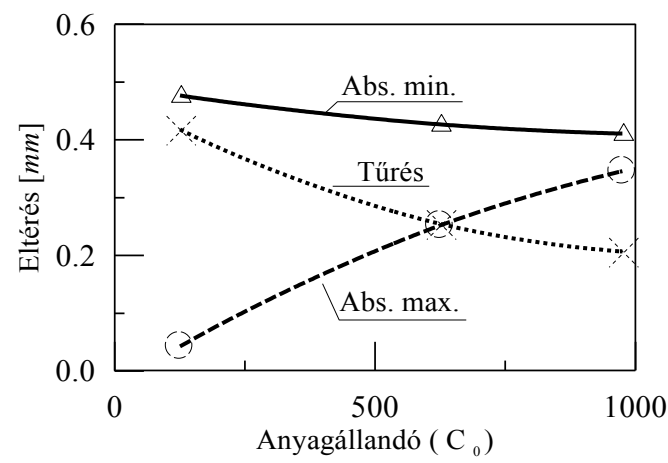

3. ábra. $\mathrm{A} \mathrm{C}_{\mathrm{O}}$ anyagállandó hatása

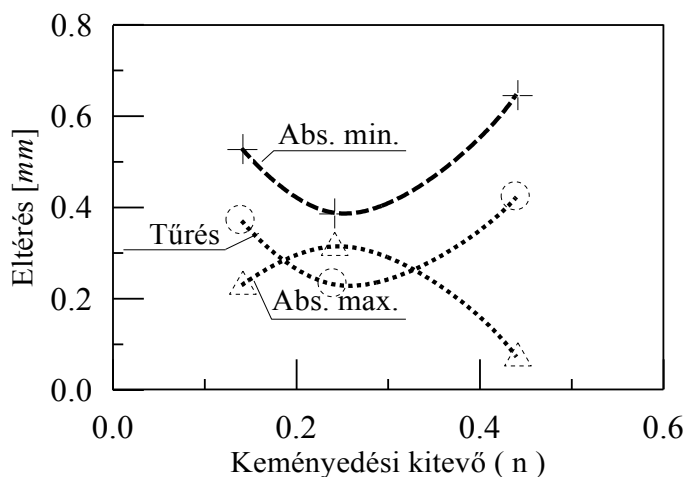

4. ábra. Az $n$ keményedési kitevő hatása 
cső anyagának jellemzőit leíró $C_{0}, n$ anyagállandók és a $\varphi_{0}$ előzetes alakítási mérték függvényében. Amint a diagramokból kitünik, ezen paraméterek jelentősen befolyásolják a végső alak alakítás utáni méreteit.

Az alakítás számítógépes szimulációjának eredményeit személtető 2. ábrán látható, hogy a csőredukálás folyamat kezdeti szakaszán az alakított csőrész méretei folyamatosan változnak a cső hossza mentén. A redukálási folyamat későbbi szakaszán az alakított

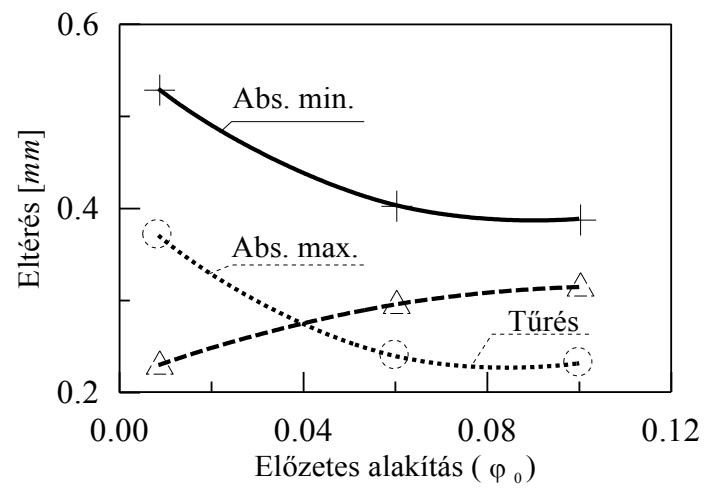

5. ábra. Az előzetes alakítás hatása csőrész átmérője a matrica kalibráló átmérőjénél kisebb méreten stabilizálódik. A bejelölt méreteltérések (abs max, abs min, tolarence) erre az állapotra vonatkoznak. Az előzőkből következik, hogy a csöveket rövid szakaszon nem lehet pontos méretüre redukálni. Ugyanis ekkor az alakított csőszakasz nem hengeres

\section{Összefoglalás}

Az anyagjellemzők vonatkozásában paraméter-vizsgálatot végeztünk a PAM-STAMP végeselemes programrendszer felhasználásával. A kiinduló cső méreteit, a redukáló szerszám geometriáját és a súrlódási tényező értékét változatlanul hagyva, vizs gáltuk az anyagjellemzők hatását az alakított csőrész méreteire. A számítási eredmények azt mutatják, hogy az anyagparaméterek jelentős hatással vannak a munkadarab végső alakjára. A kiszámított eredmények alapján lehetőség nyílik más paraméterű munkadarab esetén a redukált végső alak becslésére interpolálás útján. A csőredukálás szimulálásának ezt módszerét kellően nagy számú, célszerűen felvett kiinduló paraméterre alkalmazva olyan adatbázis nyerhető, amely a redukálásnál szerepet játszó valamennyi tényezőt: anyagparamétereken kívül, az előgyártmány méreteit, a súrlódási tényezőt és az aktív elemek geometriáját is figyelembe veszi. Egy ilyen adatbázis alapján megbízhatóan lehet meghatározni a redukált csőrész végső alakját.

\section{Irodalomjegyzék}

[1] Rowe, G. W.: Principles of Industral Metalworking Processes, E. Arnold Publisher, London, 1977.

[2] Storozhev, M. V. - Popov, E. A.:Theory of Metal Forming, Nauka i Technika, Moscow, 1976.

[3] Ebertshäuser, H.:Untersuchungen über das Einziehen (Verjüngen) von Hohlkörpen, Blech Rohre Profile, 1980, 27, N. 1. p. 6-12., N. 2. p. 86-93.

Dr. Gál Gaszton egyetemi adjunktus

Klementis Ottó doktorandus

Miskolci Egyetem Mechanikai Technológiai Tanszék

H3515 Miskolc Egyetemváros, +46-365111-1845, fax:+46-363929 